\title{
Review \\ Clinical review: Patency of the circuit in continuous renal replacement therapy
}

\author{
Michael Joannidis ${ }^{1}$ and Heleen M Oudemans-van Straaten ${ }^{2}$
}

\author{
${ }^{1}$ Medical Intensive Care Unit, Division of General Internal Medicine, Department of Internal Medicine, Medical University Innsbruck, Anichstr. 35, \\ 6020 Innsbruck, Austria \\ 2Department of Intensive Care Medicine, Onze Lieve Vrouwe Gasthuis, Oosterpark 9, 1091 AC Amsterdam, The Netherlands
}

Corresponding author: Heleen M Oudemans-van Straaten, h.m.oudemans-vanstraaten@olvg.nl

Published: 12 July 2007

This article is online at http://ccforum.com/content/11/4/218

(c) 2007 BioMed Central Ltd
Critical Care 2007, 11:218 (doi:10.1186/cc5937)

observed even without detectable systemic activation of these systems [3,4]. Some of these processes may occur locally at the membrane. Other reasons for premature clotting related to the CRRT technique are repeated stasis of blood flow [5], hemoconcentration, turbulent blood flow, and bloodair contact in air-detection chambers [6]. Circuit clotting has further been observed in association with a high platelet count and platelet transfusion [7,8]. Premature clotting reduces circuit life and efficacy of treatment and increases blood loss, workload, and costs of treatment. Therefore, improving circuit life is clinically relevant.

The interpretation of studies evaluating circuit life in CRRT, however, is hampered by the complexity and interplay of the factors mentioned. Furthermore, circuits are disconnected because of imminent clotting, protein adsorption to the membrane causing high transmembrane pressures (clogging), or logistic reasons such as transport or surgery. In addition, some units change filters routinely after 24 to 72 hours. Despite a lack of proof supported by large randomized trials, several measures seem sensible for prolonging patency of the CRRT circuit.

One major intervention to influence circuit life is anticoagulation. Given a recent review on anticoagulation strategies in CRRT [9], this overview also incorporates the role of non-anticoagulant measures for circuit survival.

\section{Non-anticoagulant measures to improve circuit life}

\section{Reducing stasis of flow}

Vascular access

Vascular access is a major determinant of circuit survival. Both high arterial and venous pressures are detrimental. Access Activation of tissue factor, leucocytes, and platelets play an additional role [2]. However, thrombin activation has been

continuous renal replacement therapy; $\mathrm{CVVH}=$ continuous venovenous aPTT = activated partial thromboplastin time; $\mathrm{AT}=$ antithrombin; CRRT $=$ continuous renal replacement therapy; $\mathrm{CVVH}=$ continuous venovenous
hemofiltration; CVVHD = continuous venovenous hemodialysis; CVVHDF $=$ continuous venovenous hemodiafiltration; HIT $=$ heparin-induced thrombocytopenia; $\mathrm{Ht}=$ hematocrit; $\mathrm{iCa}=$ ionized calcium; $\mathrm{LMWH}=$ low molecular weight heparin; $\mathrm{PF}-4=$ platelet factor-4; $\mathrm{PG}=$ prostaglandin; $\mathrm{QB}=$ blood flow; $\mathrm{OF}=$ ultrafiltrate flow; rhAPC $=$ recombinant human activated protein $\mathrm{C} ; \mathrm{UFH}=$ unfractioned heparin. 


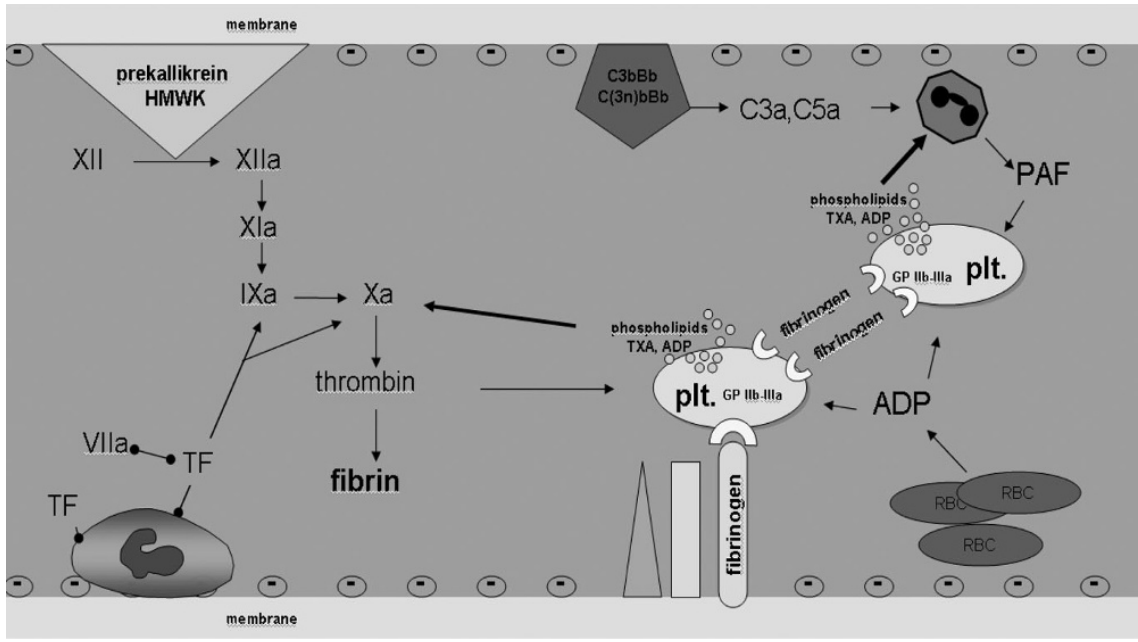

Mechanism of contact activation by hemofilter membranes. ADP, adenosine diphosphate; C, complement factor; GP, glycoprotein; HMWK, high molecular weight kininogens; PAF, platelet activating factor released by polymorphonuclear cells; plt., platelets; RBC, red blood cells; TF, tissue factor expressed by adhering monocytes; TXA, thromboxane $A_{2}$.

failure causes blood flow reductions, which are associated with early circuit clotting [5]. In vitro studies have found that high venous pressures in the circuit reduce circuit life [10]. Randomized studies in critically ill patients on CRRT which evaluate the effect of catheter site or design on circuit flow and survival are not available. Most information comes from observational and in vitro studies in chronic hemodialysis patients, who need their catheters intermittently and for a much longer time (reviewed in [11]). Some general principles are summarized in Figure 2 and are discussed below.

According to Poisseuille's law, flow through a catheter is related to the fourth power of radius and inversely related to length, indicating that a thick (13 to 14 French) and short catheter is preferable. However, a more central position of the tip improves flow, dictating sufficient length. In chronic dialysis patients, best flows are obtained with the tip in the right atrium [12,13]. With the femoral route, tip position should be positioned in the inferior caval vein. Because the inner diameter counts, the material is crucial. In general, silicone catheters have thicker walls than polyurethane catheters. Another issue is the presence of side or end holes. Flow through end holes is laminar, which is optimal, whereas flow through side holes is turbulent and even locally stagnant, contributing to early clotting. Suctioning of side holes against the vessel wall may impair flow, which is minimized with side holes over the (near) total circumference and absent with end holes. Another important determinant of catheter flow is the patient's circulation. For example, catheter dysfunction was found to be associated with low central venous pressure [12].

Furthermore, kinking of the catheter may impair catheter flow. Subclavian access has an enhanced risk of kinking and of stenosis with longer catheter stay [14-16]. The right jugular route is the straightest route. Furthermore, high abdominal pressures or high or very negative thoracic pressures, occupancy by other catheters, patency or accessibility of veins, anatomy, posture, and mobility of the patient determine choice of the site. Ultrasound-guided catheter placement significantly reduces complications [17]. An important issue is locking of the CRRT catheter when not in use by controlled saline infusion or by blocking with heparin or citrate solutions to prevent fibrin adhesion, which slowly reduces lumen diameter $[18,19]$.

\section{Training of nurses}

Slow reaction to pump alarms contributes to stasis of flow and early filter clotting. Training includes the recognition and early correction of a kinked catheter and the adequate rinsing of the filter before use since blood-air contact activates coagulation [20,21]. Intermittent saline flushes have no proven efficacy [22]. Filling of the air detection chamber to at least two thirds minimizes blood-air contact.

\section{Optimizing continuous renal replacement therapy settings}

Filtration versus dialysis

For several reasons, continuous venovenous hemofiltration (CVVH) appears to be associated with shorter circuit life than continuous venovenous hemodialysis (CVVHD) [23]. First, for the same CRRT dose, hemofiltration requires higher blood flows. Higher blood flows give more flow limitation and more frequent stasis of blood flow. Second, hemofiltration is associated with hemoconcentration, occurring as a consequence of ultrafiltration. Within the filter, hematocrit $(\mathrm{Ht})$, platelet count, and coagulation factors increase the likelihood of coagulation. Continuous venovenous hemodiafiltration 


\begin{tabular}{|c|c|c|c|}
\hline & Qualification & Pro & Con \\
\hline \multicolumn{4}{|c|}{ Characteristic of catheter } \\
\hline Diameter & Higher & $Q$ increases & Vascular occlusion \\
\hline \multirow[t]{2}{*}{ Length } & Longer & $\mathrm{Q}$ increases if the tip is in $\mathrm{RA} / \mathrm{ICV}$ & $\mathrm{Q}$ is inversely related to length \\
\hline & Shorter & $\mathrm{Q}$ increases & $\begin{array}{l}\text { Q decreases if the tip is in jugular vein } \\
\text { or iliac vein, especially with } \\
\text { hypovolemia }\end{array}$ \\
\hline \multirow[t]{3}{*}{ Material } & (Modified) polyurethane & $\begin{array}{l}\text { Thin wall: higher inner diameter } \\
\text { leads to increases in } Q\end{array}$ & Rather stiff: more kinking \\
\hline & Silicone & $\begin{array}{l}\text { High biocompatibility and less } \\
\text { thrombogenic pliancy lead to less } \\
\text { kinking }\end{array}$ & $\begin{array}{l}\text { Thicker wall: smaller inner diameter } \\
\text { leads to an increase in } \mathrm{Q}\end{array}$ \\
\hline & Heparin coating & Thrombogenicity decreases & Short duration of effect \\
\hline \multicolumn{4}{|l|}{ Design } \\
\hline Co-axial & 30 & $\begin{array}{l}\text { Side holes over entire } \\
\text { circumference: less suction to } \\
\text { vessel wall } \\
\text { Tapering tip: easy insertion }\end{array}$ & $\begin{array}{l}\text { Side holes: turbulent and stagnant } \\
\text { flow leads to clotting }\end{array}$ \\
\hline Double D & $\bigoplus_{40}$ & Tapering tip: easy insertion & $\begin{array}{l}\text { One-sided side holes: suctioning } \\
\text { against vessel wall and turbulent and } \\
\text { stagnant flow lead to clotting }\end{array}$ \\
\hline Cycle C & & $\begin{array}{l}\text { Tapering tip: easy insertion } \\
\text { Side holes over almost entire } \\
\text { circumference }\end{array}$ & Side holes (see above) \\
\hline Split tip & $\Longrightarrow$ & $\begin{array}{l}\text { No side holes: laminar flow, } \\
\text { less recirculation? }\end{array}$ & $\begin{array}{l}\text { No tapering tip: pre-dilatation is } \\
\text { important }\end{array}$ \\
\hline Shotgun & $\Longrightarrow$ & $\begin{array}{l}\text { No side holes: laminar flow, } \\
\text { less clotting? }\end{array}$ & $\begin{array}{l}\text { No tapering tip: pre-dilatation is } \\
\text { important }\end{array}$ \\
\hline Coating & Heparin & Less clotting & Short-term effect \\
\hline \multirow[t]{3}{*}{ Choice of central vein } & Jugular & $\begin{array}{l}\text { Easy access } \\
\text { Straight route } \\
\mathrm{Q} \text { increases if position is in RA }\end{array}$ & $\begin{array}{l}\text { Q decreases with high or negative } \\
\text { intra-thoracic pressures } \\
\text { Saliva contamination }\end{array}$ \\
\hline & Femoral & $\begin{array}{l}\text { Easy access } \\
\text { Rather straight route } \\
\mathrm{Q} \text { increases if position is in ICV }\end{array}$ & $\begin{array}{l}\text { Fecal contamination } \\
\mathrm{Q} \text { decreases due to longer length }\end{array}$ \\
\hline & Subclavian & $\begin{array}{l}\text { Clean site } \\
\text { Comfortable site }\end{array}$ & $\begin{array}{l}\text { Kinking } \\
\text { Risk of late vascular stenosis } \\
\text { Q decreases with high intra-thoracic } P\end{array}$ \\
\hline Position of patient & $\begin{array}{l}\mathrm{Q} \text { is linearly related to } \Delta \mathrm{P} \\
\text { over catheter }\end{array}$ & (Near) horizontal position & $\begin{array}{l}\text { Q decreases with sitting, highly } \\
\text { negative thoracic } \mathrm{P} \text {, high thoracic, or } \\
\text { intra-abdominal } \mathrm{P}\end{array}$ \\
\hline \multirow[t]{3}{*}{ Catheter 'lock' } & Intravenous saline pump & Safe & Infusion pump \\
\hline & Heparin & Effective & Minor systemic effect \\
\hline & Citrate & $\begin{array}{l}\text { Effective } \\
\text { Fewer infections } \\
\text { Less biofilm }\end{array}$ & $\begin{array}{l}\text { Risk of hypotension if not suctioned } \\
\text { before re-use }\end{array}$ \\
\hline
\end{tabular}

Features of vascular access contributing to extracorporeal blood flow. ICV, inferior caval vein; P, pressure; Q, blood flow; RA, right atrium.

(CVVHDF) combines the possible advantages of hemofiltration (higher middle molecular clearance) with less hemoconcentration. Higher solute clearances can be attained at relatively lower blood flows and may thus increase circuit survival. However, a prospective survey in children on 442 CRRT circuits (heparin and citrate) could not find a correlation between circuit survival and CRRT mode (CVVH, CVVHD, or CVVHDF) [24].

Filtration fraction or postfilter hematocrit

To minimize the procoagulant effects of hemoconcentration, it is recommended to keep the filtration fraction (the ratio of 
ultrafiltrate flow [QF] to blood flow [QB]) as low as possible; a value below $25 \%$ is generally recommended in postdilution mode. It may be more rational to adjust the filtration fraction to the patient's Ht because blood viscosity in the filter is the limiting factor. Although many factors contribute to blood viscosity, $\mathrm{Ht}$ is the main determinant and is available at bedside. A Ht in the filter $\left(\mathrm{Ht}_{\text {filter }}\right)$ of 0.40 may be acceptable. $\mathrm{Ht}_{\text {filter }}$ and the minimal $\mathrm{QB}$ required for the prescribed $\mathrm{OF}$ can be calculated at bedside.

$$
\begin{gathered}
\mathrm{Ht}_{\text {filter }}=\mathrm{QB} \times \mathrm{Ht}_{\text {patient }} /(\mathrm{QB}-\mathrm{QF}), \\
\mathrm{QB}=\mathrm{QF} \times\left(\mathrm{Ht}_{\text {filter }} /\left(\mathrm{Ht}_{\text {filter }}-\mathrm{Ht}_{\text {patient }}\right) .\right.
\end{gathered}
$$

Another option for reducing the filtration fraction is to administer (part of) the replacement fluid before the filter.

\section{Predilution versus postdilution}

In predilution CRRT, substitution fluids are administered before the filter, thus diluting the blood in the filter, decreasing hemoconcentration, and improving rheological conditions. One small randomized cross-over study $(n=15)$ and one study comparing 33 patients on predilution CVVH to 15 historical postdilution controls found longer circuit survival with predilution $[25,26]$ at the cost of a diminished clearance [26]. However, compared to the historical controls, mean daily serum creatinine changes were not significantly different [25]. Reduced filter downtime may compensate for the lower predilution clearance. Predilution particularly reduces middle molecular clearance [27], the clinical consequences of which are still unclear.

\section{Clogging}

Clogging is due to the deposition of proteins and red cells on the membrane and leads to decreased membrane permeability. Clogging is detected by declining sieving coefficients of larger molecules and increasing transmembrane pressures. Clogging enhances the blockage of hollow fibers as well. The process is still incompletely understood, but interplay between the protein constitution of plasma, rheological characteristics of blood, capillary and transmembrane flow, membrane characteristics, and possibly the use of different resuscitation fluids influence this process $[10,27]$. It has been suggested that with predilution, membrane performance is better maintained by reducing protein adsorption. On the other hand, others have shown more protein adsorption with predilution [28]. This may be explained by the higher ultrafiltration rate, opening more channels and thus increasing the actual surface and the amount of protein adsorbed. Future developments to reduce protein adsorption include hydrophilic modification of polyetersulfone [29].

\section{Membranes}

Biocompatibility is significantly influenced by membrane characteristics. Main determinants are electronegativity of membrane surface and its ability to bind plasma proteins, as well as complement activation, adhesion of platelets, and sludging of erythrocytes [30] (Figure 1). Few studies have evaluated the influence of membrane material on filter run times. Membranes with high absorptive capacity generally have a higher tendency to clot. In a non-randomized controlled study, polyamide exhibited later clotting than acrylonitrile (AN69) [31]. Modification of existing membranes to increase heparin binding (AN69ST) reduced clotting in intermittent hemodialysis [32]. Newer membranes with various polyethersulfone coatings that reduce activation of coagulation are being developed [33]. Up to now, large randomized controlled trials evaluating the influence of the type of membrane on circuit life during CRRT have been missing.

Filter size

Filter size may play a role and larger surfaces may be of relevance for filter survival and solute clearance when CVVHD is applied. A comparison of two polysulphone hemofilters with different hollow fiber lengths showed transmembrane pressure and increased survival time being lower with the longer filter [34].

\section{Anticoagulation}

Anticoagulation of the extracorporeal circuit is generally required. However, systemic anticoagulation may cause bleeding [31]. The risk of bleeding in critically ill patients is high because of frequent disruption of the vascular wall and coagulopathy. Therefore, clinicians search for alternatives such as CRRT without anticoagulation [35-38], increasing natural anticoagulants, minimal systemic anticoagulation, or regional anticoagulation.

\section{Increasing natural anticoagulants}

Heparin acts by a 1,000-fold potentiation of antithrombin (AT) to inhibit factors $\mathrm{Xa}$ and Ila (thrombin). Low levels of AT decrease heparin activity and are associated with premature clotting of the circuit $[3,39,40]$. In a non-randomized study in patients on CRRT, AT deficiency (less than 60\%) was associated with early filter clotting, whereas supplementation increased circuit life [41]. In a recent retrospective case control study in patients with septic shock undergoing CRRT with heparin, supplementation of AT to keep plasma concentration above $70 \%$ increased circuit survival time [42].

Recombinant human activated protein C (rhAPC), used in severe sepsis, inhibits the formation of thrombin by degrading coagulation factors $\mathrm{Va}$ and VIlla. Furthermore, it might decrease the synthesis and expression of tissue factor and enhance fibrinolysis [43]. During administration of rhAPC, additional anticoagulation for CRRT is probably not required [44].

\section{Minimal systemic anticoagulation}

Systemic anticoagulation inhibits plasmatic coagulation, platelet function, or both. Low-dose anticoagulation is usually sufficient to keep the filter patent and mitigates the increased 
risk of bleeding associated with full anticoagulation. Effects in the circuit are highest with local administration.

\section{Interference with plasmatic coagulation}

\section{Unfractioned heparin}

Unfractioned heparin (UFH) is the predominant anticoagulant. Its major advantages are the low costs, ease of administration, simple monitoring, and reversibility with protamine $[9,45]$. The half-life of UFH is approximately 90 minutes, increasing to up to 3 hours in renal insufficiency due to accumulation of the smaller fragments. Monitoring with activated partial thromboplastin time (aPTT) is still the best option. Retrospective analyses indicate increased bleeding if systemic aPTT is longer than 45 seconds [31]. At this low level of anticoagulation, activated clotting time is relatively insensitive for monitoring [46]. However, aPTT appears to be an unreliable predictor of bleeding $[9,47]$. Given these limitations, a possible scheme for UFH consists of a bolus of $30 \mathrm{lU} / \mathrm{kg}$ followed by an initial rate of 5 to $10 \mathrm{lU} / \mathrm{kg}$ per hour in patients with normal coagulation. However, the level of anticoagulation should be individualized. Apart from bleeding, major side effects of UFH include development of heparininduced thrombocytopenia (HIT), hypoaldosteronism, effects on serum lipids, and AT dependency [47].

\section{Low molecular weight heparins}

Low molecular weight heparins (LMWHs) exhibit several advantages, including lower incidence of HIT [48], lower AT affinity, less platelet and polymorphonuclear cell activation, less inactivation by platelet factor-4 (PF-4), higher and more constant bioavailability, and lack of metabolic side effects $[47,49,50]$. However, data on the use of LMWH in CRRT are limited [7,51-53]. Dalteparin, nadroparin, and enoxaparin have been investigated. Their mean molecular weight is between 4.5 and $6 \mathrm{kDa}$, and their mean half-life ranges from 2.5 to 6 hours and is probably even longer in renal insufficiency. However, there are indications that LMWHs are eliminated by CRRT [54]. Although some studies use LMWH in a fixed dose [7,52], continuous intravenous application of $\mathrm{LMWH}$, aiming at systemic anti-FX levels of 0.25 to $0.35 \mathrm{U} / \mathrm{ml}$, may be the safest option [53]. However, anti-Xa may not be a reliable predictor of bleeding [55] and anti-Xa determinations are not generally available.

\section{Heparin-induced thrombocytopenia}

HIT is caused by a heparin-induced antibody that binds to the heparin-PF-4 complex on the platelet surface. This may or may not lead to platelet activation and consumption, thrombocytopenia, and both arterial and venous thrombosis. Depending on the dose and type of heparin, the population, and the criteria used, $1 \%$ to $5 \%$ of treated patients develop HIT [56]. Platelet count typically rapidly decreases by more than $50 \%$ after approximately 1 week or earlier after previous use of heparin. Diagnosis depends on a combination of clinical and laboratory results [57]. A reliable diagnosis is complicated by the fact that the incidence of a false-positive enzyme-linked immunosorbent assay test is high [58]. Unfortunately, the more precise carbon 14-serotonin release assay is not routinely available. Awaiting final diagnosis, all kinds of heparins should be discontinued and an alternative anticoagulant started.

There are no randomized controlled trials showing which anticoagulant is best for HIT. The choice depends on local availability and monitoring experience. If citrate is used for anticoagulation of the circuit, separate thromboprophylaxis must be applied. Inhibition of thrombin generation can be obtained via direct inhibition of Flla (r-hirudin, argatroban, or dermatan sulphate), FXa (danaparoid or fondaparinux), or both (nafamostat). Inhibition of platelet activation can be obtained by the use of prostaglandins (PGs) (summarized in $[9,59]$ ). The use of $r$-hirudin is discouraged because of severe adverse events, extremely long half-life (170 to 360 hours), and the requirement of ecarin clotting time for monitoring [60]. Given the long half-life of fondaparinux and danaparoid (more than 24 hours), monitoring of anti- $\mathrm{Xa}$ is mandatory. The clinical relevance of cross-reactivity of danaparoid with HIT antibodies is not known [61]. Argatroban might be preferred because it is cleared by the liver and monitoring with aPTT seems feasible [62-65]. The half-life is approximately 35 minutes in chronic dialysis, but longer in the critically ill. Up to now, clinical data in CRRT and availability of the drug have been limited.

\section{Interference with platelet activation}

Inhibition of platelet activation by PGs appears to be justified because the extracorporeal generation of thrombin and the use of heparin cause platelet activation. Both $P G E_{1}$ and $\mathrm{PGI}_{2}$ have been investigated in CRRT, alone or in combination with heparins. The exclusive use of PGs in CVVH (1.5 liters per hour in predilution) provided a rather short circuit survival (median, 15 hours) [66]. Nevertheless, PGs may be a safe initial alternative when HIT is suspected. They can even be used in patients with hepatic and renal failure [67]. Significant improvement of circuit survival, however, could be achieved only when PGs were combined with low-dose UFH or LMWH [68-70]. PGs are administered in doses of 2 to $5 \mathrm{ng} / \mathrm{kg}$ per minute. Major drawbacks for routine use are their high costs and hypotension due to vasodilatation, but the half-life of the vasodilatory effect is as short as 2 minutes.

\section{Regional anticoagulation with citrate}

\section{Anticoagulation}

Regional anticoagulation can be achieved by the prefilter infusion of citrate. Citrate chelates calcium, decreasing ionized calcium ( $\mathrm{iCa}$ ) in the extracorporeal circuit. For optimal anticoagulation, citrate flow is adjusted to blood flow, targeting at a concentration of 3 to $5 \mathrm{mmol} / \mathrm{l}$ in the filter [71]. Postfilter iCa can be used for fine tuning of the level of anticoagulation, aiming at a concentration of $\mathrm{iCa}$ of less than $0.35 \mathrm{mmol} / \mathrm{l}$ (Table 1). However, others prefer a fixed citrate dose and do not monitor $\mathrm{iCa}$ in the circuit, thereby simplifying the procedure (summarized in [9]). Citrate is partially 
Table 1

Different options for adjustment of anticoagulation with citrate

\begin{tabular}{lll}
\hline Anticoagulant target & Pro & Con \\
\hline Calculated [citrate] in filter 3-5 mmol/l & $\begin{array}{l}\text { Fixed ratio of citrate flow and blood flow } \\
\text { No extra monitoring } \\
\text { Fixed buffer supply to patient }\end{array}$ & Anticoagulation may not be optimal \\
{$\left[\mathrm{iCa}^{++}\right.$] postfilter $0.25-0.35 \mathrm{mmol} / \mathrm{l}$} & Optimal anticoagulation & $\begin{array}{l}\text { Monitoring of postfilter iCa } \\
\text { Adjustment of citrate flow gives varying buffer } \\
\text { supply to patient }\end{array}$ \\
\hline
\end{tabular}

$\mathrm{iCa}^{++}$, ionized calcium.

removed by convection or diffusion and partially enters the systemic circulation, where $\mathrm{iCa}$ rises again due to the dilution of extracorporeal blood, the liberation of chelated calcium when citrate is metabolized, and the replacement of calcium. As a result, systemic effects on coagulation do not occur.

Buffer

Apart from being an anticoagulant, citrate is a buffer substrate. The generation of buffer is related to the conversion of sodium citrate to citric acid:

$$
\begin{gathered}
\mathrm{Na}_{3} \text { citrate }+3 \mathrm{H}_{2} \mathrm{CO}_{3} \rightarrow \\
\text { citric acid }\left(\mathrm{C}_{6} \mathrm{H}_{8} \mathrm{O}_{7}\right)+3 \mathrm{NaHCO}_{3}
\end{gathered}
$$

Citric acid enters the mitochondria and is metabolized in the Krebs cycle, mainly in the liver but also in skeletal muscle and the renal cortex, leaving sodium bicarbonate.

Removal and accumulation of citrate

Citrate removal by CRRT mainly depends on CRRT dose and not on modality. Citrate clearance approximates urea clearance. The sieving coefficient is between 0.87 and 1.0 and is not different between CVVH and CVVHD [72,73]. Citrate removal with CRRT also depends on citrate concentration in the filter and filtration fraction; high fractions are associated with relatively higher citrate clearance and a lower buffer supply to the patient.

The use of regional anticoagulation with citrate is limited by the patient's capacity to metabolize citrate, which is decreased if liver function or tissue perfusion fails [74]. Due to the citrate load associated with transfusion, patients having received a massive transfusion are also at risk of citrate accumulation. If citrate accumulates, iCa decreases and metabolic acidosis ensues, since bicarbonate continues to be removed by filtration or dialysis, while citrate is not used as a buffer. In daily clinical practice, citrate measurement is hampered by the limited stability of the reagents. However, accumulation of citrate due to decreased metabolism can be detected accurately by the symptoms of metabolic acidosis, increasing anion gap, ionized hypocalcemia, and most specifically by an increased total/iCa concentration. A ratio of more than 2.1 predicted a citrate concentration of greater than $1 \mathrm{mmol} / \mathrm{l}$ with $89 \%$ sensitivity and $100 \%$ specificity [71]. Others use a ratio of more than 2.5 for accumulation [75].

Accumulation of citrate can also be the result of an unintended citrate over-infusion or of decreased removal in case of a decline in membrane performance at constant citrate infusion. In these cases, ionized hypocalcemia occurs together with metabolic alkalosis. Both derangements are preventable by adherence to the protocol or are detectable early by strict monitoring.

\section{Metabolic consequences}

Anticoagulation with citrate has complex metabolic consequences, which are related to the dual effects of citrate as an anticoagulant and a buffer. Manipulation of citrate or blood flow, ultrafiltrate, dialysate, or replacement rates, and their mutual relation changes the amount of buffer substrate entering the patient's circulation. For a constant buffer delivery, these flows are to be kept constant, while they can be adjusted to correct metabolic acidosis or alkalosis. Causes of metabolic derangements and possible adjustments are summarized in Table 2.

\section{Citrate solutions}

Citrate is either infused as a separate tri-sodium citrate solution or added to a calcium-free predilution replacement fluid. The strength of citrate solutions is generally expressed as a percentage (grams of tri-sodium citrate per $100 \mathrm{ml}$ ). Some of the solutions contain additional citric acid to reduce sodium load. Because anticoagulatory strength of the solution depends on the citrate concentration, it is best expressed as molar strength of citrate. Citrate solutions for postdilution CVVH(D) contain 133 to $1,000 \mathrm{mmol}$ citrate per liter [73,75-82]. Citrate replacement solutions for predilution CVVH contain 11 to $15 \mathrm{mmol}$ citrate per liter [83-88] and for predilution CVVHDF, 13 to $23 \mathrm{mmol} / /$ [40,89-92]. The buffer strength of the solution is related to the conversion of trisodium citrate to citric acid (see formula above) and therefore to the proportion of sodium as cation.

\section{Modalities}

After the first report of Mehta and colleagues [76], a wide variety of homemade citrate systems for CRRT have been 
Table 2

\begin{tabular}{|c|c|c|}
\hline Derangement & Cause and signs & Adjustment \\
\hline \multirow[t]{3}{*}{ Metabolic acidosis } & $\begin{array}{l}\text { Insufficient removal of metabolic acids } \\
\text { Anion gap increases }\end{array}$ & $\begin{array}{l}\text { Increase continuous renal replacement therapy dose } \\
\text { (filtrate or dialysate flow) to } 35 \mathrm{ml} / \mathrm{kg} \text { per hour }\end{array}$ \\
\hline & Loss of buffer substrate is higher than delivery & $\begin{array}{l}\text { Increase bicarbonate replacement } \\
\text { or increase bicarbonate dialysate flow } \\
\text { or give additional bicarbonate } \\
\text { or increase citrate flow (cave accumulation) }\end{array}$ \\
\hline & $\begin{array}{l}\text { Citrate metabolism decreases (iCa decreases, } \\
\text { totCa/iCa increases [more than 2.1-2.5], and anion } \\
\text { gap increases) }\end{array}$ & $\begin{array}{l}\text { Decrease citrate delivery or stop } \\
\text { increase dialysate or filtrate flow } \\
\text { increase bicarbonate replacement } \\
\text { or increase bicarbonate dialysate flow }\end{array}$ \\
\hline \multirow[t]{2}{*}{ Metabolic alkalosis } & Delivery of buffer substrate is higher than loss & $\begin{array}{l}\text { Decrease bicarbonate replacement } \\
\text { or decrease bicarbonate dialysate flow } \\
\text { or stop additional bicarbonate i.v. } \\
\text { or decrease citrate flow (cave anticoagulation) }\end{array}$ \\
\hline & $\begin{array}{l}\text { Decreased loss of buffer due to a decline in } \\
\text { filtrate flow }\end{array}$ & $\begin{array}{l}\text { Change filter } \\
\text { Increase filtrate flow }\end{array}$ \\
\hline \multirow[t]{2}{*}{ Hypocalcemia } & $\begin{array}{l}\text { Loss of calcium is higher than delivery (iCa decreases } \\
\text { and totCa/iCa is normal) }\end{array}$ & Increase i.v. calcium dose \\
\hline & $\begin{array}{l}\text { Citrate metabolism decreases (metabolic acidosis, } \\
\text { totCa/iCa increases, and anion gap increases) }\end{array}$ & $\begin{array}{l}\text { Increase i.v. calcium dose, } \\
\text { decrease or stop citrate delivery } \\
\text { increase dialysate or filtrate flow, } \\
\text { increase bicarbonate replacement } \\
\text { or increase bicarbonate dialysate flow }\end{array}$ \\
\hline Hypercalcemia & Delivery of calcium is higher than loss & Decrease i.v. calcium dose \\
\hline \multirow[t]{2}{*}{ Hypernatremia } & Delivery of sodium is higher than loss & $\begin{array}{l}\text { Recalculate default settings } \\
\text { Protocol violation } \\
\text { - decrease sodium replacement } \\
\text { - decrease dialysate sodium content } \\
\text { - decrease trisodium citrate flow }\end{array}$ \\
\hline & $\begin{array}{l}\text { Decreased loss of sodium due to a decline in } \\
\text { filtrate flow }\end{array}$ & Change filter \\
\hline Hyponatremia & Loss of sodium is higher than delivery & $\begin{array}{l}\text { Recalculate default settings } \\
\text { Protocol violation } \\
\text { - increase sodium replacement } \\
\text { - increase dialysate sodium content } \\
\text { - increase trisodium citrate flow }\end{array}$ \\
\hline
\end{tabular}

$\mathrm{iCa}$, ionized calcium; i.v., intravenous; totCa/iCa, ratio of total to ionized calcium.

described. There are systems for CVVHD, predilutional or postdilutional CVVH, CVVHDF, and different doses of CRRT (1.5 to 4 liters per hour) (summarized in the electronic supplemental material in [9]). None of the proposed systems can attain perfect acid-base control using one standard citrate, replacement, or dialysis solution. Each protocol has its own rules to correct metabolic acidosis or alkalosis or hypocalcemia or hypercalcemia.

\section{Circuit survival and bleeding complications}

Some of the published studies compare circuit life and bleeding complications with citrate to historical or contemporary non-randomized controls on heparin (summarized in [9]) [93-95]. Because the citrate patients often had a higher risk of bleeding, groups are generally not comparable. Nevertheless, bleeding complications were generally reduced in the citrate groups. Circuit survival with citrate was usually improved (summarized in [9]) [93], sometimes comparable $[24,84,95]$, and in some studies shorter than with heparin $[89,94]$. Differences in circuit life between studies can be explained in part by the wide variety of citrate dose (2 to $6 \mathrm{mmol} / \mathrm{l}$ blood flow), fixed citrate infusion or citrate dose titrated on postfilter $\mathrm{iCa}$, the use of dialysis or filtration (predilution or postdilution), differences in CRRT dose and filtration fraction, or by a reduction in citrate flow used for control of metabolic alkalosis. Only two small randomized controlled studies comparing anticoagulation with citrate to UFH have appeared in a full paper. Both show a significantly 


\section{This article is part of a review series on Renal replacement therapy, edited by John Kellum and Lui Forni.}

Other articles in the series can be found online at http://ccforum.com/articles/ theme-series.asp?series=CC_Renal

longer circuit survival with citrate $[40,82]$, a trend toward less bleeding [40], and less transfusion with citrate [82].

\section{Safety of citrate}

It may be questioned whether the benefits of citrate (less bleeding, possibly a longer circuit survival, and less bioincompatibility [96-98]) weigh against the greater risk of metabolic derangement and possible long-term side effects like increased bone resorption [99]. Preliminary results from a large randomized controlled trial (of approximately 200 patients) comparing regional anticoagulation with citrate to nadroparin in postdilution CVVH show that citrate is safe and superior in terms of mortality to nadroparin (H.M. Oudemansvan Straaten, to be published).

\section{Conclusion}

Premature clotting of the CRRT circuit increases blood loss, workload, and costs. Circuit patency can be increased. Nonanticoagulation measures include optimization of vascular access (inner diameter, pattern of flow, and position), CRRT settings (partial predilution and individualized control of filtration fraction), and the training of nurses. Systemic anticoagulation interferes with plasmatic coagulation, platelet activation, or both and should be kept at a low dose to mitigate bleeding complications. Regional anticoagulation with citrate emerges as the most promising method.

\section{Competing interests}

The authors declare that they have no competing interests.

\section{References}

1. Levi M, Opal SM: Coagulation abnormalities in critically ill patients. Crit Care 2006, 10:222.

2. Cardigan RA, McGloin H, Mackie IJ, Machin SJ, Singer M: Activation of the tissue factor pathway occurs during continuous venovenous hemofiltration. Kidney Int 1999, 55:1568-1574.

3. Salmon J, Cardigan R, Mackie I, Cohen SL, Machin S, Singer M: Continuous venovenous haemofiltration using polyacrylonitrile filters does not activate contact system and intrinsic coagulation pathways. Intensive Care Med 1997, 23:38-43.

4. Bouman CS, de Pont AC, Meijers JC, Bakhtiari K, Roem D, Zeerleder S, Wolbink G, Korevaar JC, Levi M, de Jonge E: The effects of continuous venovenous hemofiltration on coagulation activation. Crit Care 2006, 10:R150.

5. Baldwin I, Bellomo R, Koch B: Blood flow reductions during continuous renal replacement therapy and circuit life. Intensive Care Med 2004, 30:2074-2079.

6. Holt AW, Bierer P, Bersten AD, Bury LK, Vedig AE: Continuous renal replacement therapy in critically ill patients: monitoring circuit function. Anaesth Intensive Care 1996, 24:423-429.

7. de Pont AC, Oudemans-van Straaten HM, Roozendaal KJ, Zandstra DF: Nadroparin versus dalteparin anticoagulation in highvolume, continuous venovenous hemofiltration: a double- blind, randomized, crossover study. Crit Care Med 2000, 28: 421-425.

8. Cutts MW, Thomas AN, Kishen R: Transfusion requirements during continuous veno-venous haemofiltration: the importance of filter life. Intensive Care Med 2000, 26:1694-1697.

9. Oudemans-van Straaten HM, Wester JP, de Pont AC, Schetz MR: Anticoagulation strategies in continuous renal replacement therapy: can the choice be evidence based? Intensive Care Med 2006, 32:188-202.

10. Unger JK, Haltern C, Portz B, Dohmen B, Gressner A, Rossaint R: Relation of haemofilter type to venous catheter resistance is crucial for filtration performance and haemocompatibility in CVVH-an in vitro study. Nephrol Dial Transplant 2006, 21: 2191-2201.

11. Canaud B, Desmeules S, Klouche K, Leray-Moragues H, Beraud $\mathrm{JJ}$ : Vascular access for dialysis in the intensive care unit. Best Pract Res Clin Anaesthesio/ 2004, 18:159-174.

12. Jean G, Chazot C, Vanel T, Charra B, Terrat JC, Calemard E, Laurent G: Central venous catheters for haemodialysis: looking for optimal blood flow. Nephrol Dial Transplant 1997, 12:1689-1691.

13. Mandolfo S, Borlandelli S, Ravani P, Imbasciati E: How to improve dialysis adequacy in patients with vascular access problems. J Vasc Access 2006, 7:53-59.

14. Hernández D, Díaz F, Rufino $M$, Lorenzo V, Pérez $T$, Rodríguez $A$, De Bonis E, Losada M, González-Posada JM, Torres A: Subclavian vascular access stenosis in dialysis patients: natural history and risk factors. J Am Soc Nephrol 1998, 9:1507-1510.

15. Agraharkar $M$, Isaacson $S$, Mendelssohn $D$, Muralidharan J, Mustata S, Zevallos G, Besley M, Uldall R: Percutaneously inserted silastic jugular hemodialysis catheters seldom cause jugular vein thrombosis. ASAIO J 1995, 41:169-172.

16. Oliver MJ: Acute dialysis catheters. Semin Dial 2001, 14:432435.

17. Karakitsos D, Labropoulos N, De Groot E, Patrianakos AP, Kouraklis G, Poularas J, Samonis G, Tsoutsos DA, Konstadoulakis $\mathrm{MM}$, Karabinis A: Real-time ultrasound-guided catheterisation of the internal jugular vein: a prospective comparison with the landmark technique in critical care patients. Crit Care 2006 10:R162.

18. Weijmer MC, van den Dorpel MA, Van de Ven PJ, ter Wee PM, van Geelen JA, Groeneveld JO, van Jaarsveld BC, Koopmans MG, le Poole CY, Schrander-Van der Meer AM, et al.; CITRATE Study Group: Randomized, clinical trial comparison of trisodium citrate $30 \%$ and heparin as catheter-locking solution in hemodialysis patients. J Am Soc Nephrol 2005, 16:2769-2777.

19. Grudzinski L, Quinan $P$, Kwok S, Pierratos A: Sodium citrate $4 \%$ locking solution for central venous dialysis catheters-an effective, more cost-efficient alternative to heparin. Nephrol Dial Transplant 2007, 22:471-476.

20. Davies H, Leslie G: Maintaining the CRRT circuit: non-anticoagulant alternatives. Aust Crit Care 2006, 19:133-138.

21. Schetz $\mathrm{M}$ : Anticoagulation in continuous renal replacement therapy. Contrib Nephrol 2001, (132):283-303.

22. Ramesh Prasad GV, Palevsky PM, Burr R, Lesko JM, Gupta B, Greenberg A: Factors affecting system clotting in continuous renal replacement therapy: results of a randomized, controlled trial. Clin Nephrol 2000, 53:55-60.

23. Ricci Z, Ronco C, Bachetoni A, D'amico G, Rossi S, Alessandri E, Rocco M, Pietropaoli P: Solute removal during continuous renal replacement therapy in critically ill patients: convection versus diffusion. Crit Care 2006, 10:R67.

24. Brophy PD, Somers MJ, Baum MA, Symons JM, McAfee N, Fortenberry JD, Rogers K, Barnett J, Blowey D, Baker C, et al.: Multi-centre evaluation of anticoagulation in patients receiving continuous renal replacement therapy (CRRT). Nephrol Dial Transplant 2005, 20:1416-1421.

25. Uchino S, Fealy N, Baldwin I, Morimatsu H, Bellomo R: Pre-dilution vs. post-dilution during continuous veno-venous hemofiltration: impact on filter life and azotemic control. Nephron Clin Pract 2003, 94:c94-c98.

26. Van der Voort PH, Gerritsen RT, Kuiper MA, Egbers PH, Kingma WP, Boerma EC: Filter run time in CVVH: pre- versus postdilution and nadroparin versus regional heparin-protamine anticoagulation. Blood Purif 2005, 23:175-180.

27. Clark WR, Gao D: Low-molecular weight proteins in end-stage renal disease: potential toxicity and dialytic removal mecha- 
nisms. J Am Soc Nephrol 2002, 13 Suppl 1:S41-S47.

28. Padrini R, Canova C, Conz P, Mancini E, Rizzioli E, Santoro A: Convective and adsorptive removal of beta2-microglobulin during predilutional and postdilutional hemofiltration. Kidney Int 2005, 68:2331-2337.

29. Zhu LP, Zhang XX, Xu L, Du CH, Zhu BK, Xu YY: Improved protein-adsorption resistance of polyethersulfone membranes via surface segregation of ultrahigh molecular weight poly(styrene-alt-maleic anhydride). Colloids Surf B Biointerfaces 2007, 57:189-197.

30. Chanard J, Lavaud S, Randoux C, Rieu P: New insights in dialysis membrane biocompatibility: relevance of adsorption properties and heparin binding. Nephrol Dial Transplant 2003, 18: 252-257.

31. van de Wetering J, Westendorp RG, van der Hoeven JG, Stolk $B$, Feuth JD, Chang PC: Heparin use in continuous renal replacement procedures: the struggle between filter coagulation and patient hemorrhage. J Am Soc Nephrol 1996, 7: 145-150.

32. Lavaud S, Canivet E, Wuillai A, Maheut H, Randoux C, Bonnet JM, Renaux $\mathrm{JL}$, Chanard J: Optimal anticoagulation strategy in haemodialysis with heparin-coated polyacrylonitrile membrane. Nephrol Dial Transplant 2003, 18:2097-2104.

33. Sperling C, Houska M, Brynda E, Streller U, Werner C: In vitro hemocompatibility of albumin-heparin multilayer coatings on polyethersulfone prepared by the layer-by-layer technique. $J$ Biomed Mater Res A 2006, 76:681-689.

34. Dungen HD, von HC, Ronco C, Kox WJ, Spies CD: Renal replacement therapy: physical properties of hollow fibers influence efficiency. Int J Artif Organs 2001, 24:357-366.

35. Bellomo $\mathrm{R}$, Teede $\mathrm{H}$, Boyce $\mathrm{N}$ : Anticoagulant regimens in acute continuous hemodiafiltration: a comparative study. Intensive Care Med 1993, 19:329-332.

36. Tan HK, Baldwin I, Bellomo R: Continuous veno-venous hemofiltration without anticoagulation in high-risk patients. Intensive Care Med 2000, 26:1652-1657.

37. Fiore G, Donadio PP, Gianferrari P, Santacroce C, Guermani A: CVVH in postoperative care of liver transplantation. Minerva Anestesiol 1998, 64:83-87.

38. Uchino S, Fealy N, Baldwin I, Morimatsu H, Bellomo R: Continuous venovenous hemofiltration without anticoagulation. ASAIO J 2004, 50:76-80.

39. Bastien O, French P, Paulus S, Filley S, Berruyer M, Dechavanne $M$, Estanove S: Antithrombin III deficiency during continuous venovenous hemodialysis. Contrib Nephrol 1995, 116:154158.

40. Kutsogiannis DJ, Gibney RT, Stollery D, Gao J: Regional citrate versus systemic heparin anticoagulation for continuous renal replacement in critically ill patients. Kidney Int 2005, 67:23612367.

41. Joannes-Boyau O, Laffargue M, Honore $P$, Gauche B, Fleureau C, Roze H, Janvier G: Short filter life span during hemofiltration in sepsis: antithrombine (AT) supplementation should be a good way to sort out this problem. Blood Purif 2005, 23:149174.

42. du Cheyron D, Bouchet B, Bruel C, Daubin C, Ramakers M, Charbonneau P: Antithrombin supplementation for anticoagulation during continuous hemofiltration in critically ill patients with septic shock: a case-control study. Crit Care 2006, 10:R45.

43. Esmon CT: The protein C pathway. Chest 2003, 124:26S-32S.

44. de Pont AC, Bouman CS, de Jonge E, Vroom MB, Büller HR, Levi $M$ : Treatment with recombinant human activated protein $C$ obviates additional anticoagulation during continuous venovenous hemofiltration in patients with severe sepsis. Intensive Care Med 2003, 29:1205.

45. Ricci Z, Ronco C, D'amico G, De Felice R, Rossi S, Bolgan I, Bonello M, Zamperetti N, Petras D, Salvatori G, et al.: Practice patterns in the management of acute renal failure in the critically ill patient: an international survey. Nephrol Dial Transplant 2006, 21:690-696.

46. De Waele JJ, Van Cauwenberghe S, Hoste E, Benoit D, Colardyn F: The use of the activated clotting time for monitoring heparin therapy in critically ill patients. Intensive Care Med 2003, 29:325-328.

47. Hirsh J, Raschke R: Heparin and low-molecular-weight heparin: the Seventh ACCP Conference on Antithrombotic and Thrombolytic Therapy. Chest 2004, 126:188S-203S
48. Warkentin TE, Levine MN, Hirsh J, Horsewood P, Roberts RS Gent M, Kelton JG: Heparin-induced thrombocytopenia in patients treated with low-molecular-weight heparin or unfractionated heparin. N Engl J Med 1995, 332:1330-1335.

49. Elisaf MS, Germanos NP, Bairaktari HT, Pappas MB, Koulouridis El, Siamopoulos KC: Effects of conventional vs. low-molecularweight heparin on lipid profile in hemodialysis patients. $\mathrm{Am} J$ Nephrol 1997, 17:153-157.

50. Leitienne $P$, Fouque D, Rigal D, Adeleine P, Trzeciak MC, Laville $\mathrm{M}$ : Heparins and blood polymorphonuclear stimulation in haemodialysis: an expansion of the biocompatibility concept. Nephrol Dial Transplant 2000, 15:1631-1637.

51. Jeffrey RF, Khan AA, Douglas JT, Will EJ, Davison AM: Anticoagulation with low molecular weight heparin (Fragmin) during continuous hemodialysis in the intensive care unit. Artif Organs 1993, 17:717-720.

52. Reeves JH, Cumming AR, Gallagher L, O'Brien JL, Santamaria JD: A controlled trial of low-molecular-weight heparin (dalteparin) versus unfractionated heparin as anticoagulant during continuous venovenous hemodialysis with filtration. Crit Care Med 1999, 27:2224-2228.

53. Joannidis $M$, Kountchev J, Rauchenzauner $M$, Schusterschitz $N$, Ulmer $\mathrm{H}$, Mayr A, Bellmann R: Enoxaparin versus unfractioned heparin for anticoagulation during continuous veno-venous hemofiltration - a randomized controlled cross-over study. Intensive Care Med 2007 Jun 12; [Epub ahead of print].

54. Isla A, Gascón AR, Maynar J, Arzuaga A, Corral E, Martín A, Solinís MA, Muñoz JL: In vitro and in vivo evaluation of enoxaparin removal by continuous renal replacement therapies with acrylonitrile and polysulfone membranes. Clin Ther 2005, 27: 1444-1451.

55. Greaves M: Limitations of the laboratory monitoring of heparin therapy. Scientific and Standardization Committee Communications: on behalf of the Control of Anticoagulation Subcommittee of the Scientific and Standardization Committee of the International Society of Thrombosis and Haemostasis. Thromb Haemost 2002, 87:163-164.

56. Warkentin TE, Greinacher A: Heparin-induced thrombocytopenia: recognition, treatment, and prevention: the Seventh ACCP Conference on Antithrombotic and Thrombolytic Therapy. Chest 2004, 126:311S-337S.

57. Wester JP, Oudemans-van Straaten HM: How do I diagnose HIT? Neth J Crit Care 2006, 10:61-65.

58. Verma AK, Levine M, Shalansky SJ, Carter CJ, Kelton JG: Frequency of heparin-induced thrombocytopenia in critical care patients. Pharmacotherapy 2003, 23:745-753.

59. Wester JP, Leyte A, Oudemans-van Straaten HM, Bosman RJ, van der Spoel JI, Haak EA, Porcelijn L, Zandstra DF: Low-dose fondaparinux in suspected heparin-induced thrombocytopenia in the critically ill. Neth J Med 2007, 65:101-108.

60. Vargas Hein O, von Heymann C, Lipps M, Ziemer S, Ronco C, Neumayer HH, Morgera S, Welte M, Kox WJ, Spies C: Hirudin versus heparin for anticoagulation in continuous renal replacement therapy. Intensive Care Med 2001, 27:673-679.

61. Magnani HN: Heparin-induced thrombocytopenia (HIT): an overview of 230 patients treated with orgaran (Org 10172). Thromb Haemost 1993, 70:554-561.

62. Dager WE, White RH: Argatroban for heparin-induced thrombocytopenia in hepato-renal failure and CVVHD. Ann Pharmacother 2003, 37:1232-1236.

63. Williamson DR, Boulanger I, Tardif M, Albert M, Gregoire G: Argatroban dosing in intensive care patients with acute renal failure and liver dysfunction. Pharmacotherapy 2004, 24:409414.

64. Tang IY, Cox DS, Patel K, Reddy BV, Nahlik L, Trevino S, Murray PT: Argatroban and renal replacement therapy in patients with heparin-induced thrombocytopenia. Ann Pharmacother 2005, 39:231-236.

65. Murray PT, Reddy BV, Grossman EJ, Hammes MS, Trevino S, Ferrell J, Tang I, Hursting MJ, Shamp TR, Swan SK: A prospective comparison of three argatroban treatment regimens during hemodialysis in end-stage renal disease. Kidney Int 2004, 66:2446-2453

66. Fiaccadori E, Maggiore U, Rotelli C, Minari M, Melfa L, Cappè G, Cabassi A: Continuous haemofiltration in acute renal failure with prostacyclin as the sole anti-haemostatic agent. Intensive Care Med 2002, 28:586-593. 
67. Davenport A, Will EJ, Davison AM: Comparison of the use of standard heparin and prostacyclin anticoagulation in spontaneous and pump-driven extracorporeal circuits in patients with combined acute renal and hepatic failure. Nephron 1994 , 66:431-437.

68. Kozek-Langenecker SA, Kettner SC, Oismueller C, Gonano C, Speiser W, Zimpfer M: Anticoagulation with prostaglandin E1 and unfractionated heparin during continuous venovenous hemofiltration. Crit Care Med 1998, 26:1208-1212.

69. Kozek-Langenecker SA, Spiss CK, Gamsjager T, Domenig C, Zimpfer M: Anticoagulation with prostaglandins and unfractionated heparin during continuous venovenous haemofiltration: a randomized controlled trial. Wien Klin Wochenschr 2002, 114:96-101.

70. Kozek-Langenecker SA, Spiss CK, Michalek-Sauberer A, Felfernig M, Zimpfer M: Effect of prostacyclin on platelets, polymorphonuclear cells, and heterotypic cell aggregation during hemofiltration. Crit Care Med 2003, 31:864-868.

71. Bakker AJ, Boerma EC, Keidel H, Kingma $P$, van der Voort $P H$ : Detection of citrate overdose in critically ill patients on citrateanticoagulated venovenous haemofiltration: use of ionised and total/ionised calcium. Clin Chem Lab Med 2006, 44:962966.

72. Chadha V, Garg U, Warady BA, Alon US: Citrate clearance in children receiving continuous venovenous renal replacement therapy. Pediatr Nephrol 2002, 17:819-824.

73. Swartz R, Pasko D, O'Toole J, Starmann B: Improving the delivery of continuous renal replacement therapy using regional citrate anticoagulation. Clin Nephrol 2004, 61:134-143.

74. Kramer L, Bauer E, Joukhadar C, Strobl W, Gendo A, Madl C, Gangl A: Citrate pharmacokinetics and metabolism in cirrhotic and noncirrhotic critically ill patients. Crit Care Med 2003, 31: 2450-2455.

75. Meier-Kriesche HU, Gitomer J, Finkel K, DuBose T: Increased total to ionized calcium ratio during continuous venovenous hemodialysis with regional citrate anticoagulation. Crit Care Med 2001, 29:748-752.

76. Mehta RL, McDonald BR, Aguilar MM, Ward DM: Regional citrate anticoagulation for continuous arteriovenous hemodialysis in critically ill patients. Kidney Int 1990, 38:976981.

77. Ward DM, Mehta RL: Extracorporeal management of acute renal failure patients at high risk of bleeding. Kidney Int Suppl 1993, 41:S237-S244.

78. Tolwani AJ, Campbell RC, Schenk MB, Allon M, Warnock DG: Simplified citrate anticoagulation for continuous renal replacement therapy. Kidney Int 2001, 60:370-374.

79. Tobe SW, Aujla P, Walele AA, Oliver MJ, Naimark DM, Perkins NJ, Beardsall $M$ : A novel regional citrate anticoagulation protocol for CRRT using only commercially available solutions. J Crit Care 2003, 18:121-129.

80. Mitchell A, Daul AE, Beiderlinden M, Schafers RF, Heemann U, Kribben A, Peters J, Philipp T, Wenzel RR: A new system for regional citrate anticoagulation in continuous venovenous hemodialysis (CVVHD). Clin Nephrol 2003, 59:106-114.

81. Morgera S, Scholle C, Voss G, Haase M, Vargas-Hein O, Krausch D, Melzer C, Rosseau S, Zuckermann-Becker $\mathrm{H}$, Neumayer $\mathrm{HH}$ : Metabolic complications during regional citrate anticoagulation in continuous venovenous hemodialysis: single-center experience. Nephron Clin Pract 2004, 97:c131-c136.

82. Monchi M, Berghmans D, Ledoux D, Canivet JL, Dubois B, Damas $P$ : Citrate vs. heparin for anticoagulation in continuous venovenous hemofiltration: a prospective randomized study. Intensive Care Med 2004, 30:260-265.

83. Palsson R, Niles JL: Regional citrate anticoagulation in continuous venovenous hemofiltration in critically ill patients with a high risk of bleeding. Kidney Int 1999, 55:1991-1997.

84. Thoenen M, Schmid ER, Binswanger U, Schuepbach R, Aerne D, Schmidlin D: Regional citrate anticoagulation using a citratebased substitution solution for continuous venovenous hemofiltration in cardiac surgery patients. Wien Klin Wochenschr 2002, 114:108-114.

85. Hofmann RM, Maloney C, Ward DM, Becker BN: A novel method for regional citrate anticoagulation in continuous venovenous hemofiltration (CVVHF). Ren Fail 2002, 24:325-335.

86. Egi M, Naka T, Bellomo R, Cole L, French C, Trethewy C, Wan L, Langenberg CC, Fealy N, Baldwin I: A comparison of two citrate anticoagulation regimens for continuous veno-venous hemofiltration. Int J Artif Organs 2005, 28:1211-1218.

87. Naka T, Egi M, Bellomo R, Cole L, French C, Botha J, Wan L, Fealy N, Baldwin I: Commercial low-citrate anticoagulation haemofiltration in high risk patients with frequent filter clotting. Anaesth Intensive Care 2005, 33:601-608.

88. Bihorac $A$, Ross $E A$ : Continuous venovenous hemofiltration with citrate-based replacement fluid: efficacy, safety, and impact on nutrition. Am J Kidney Dis 2005, 46:908-918.

89. Gabutti L, Marone C, Colucci G, Duchini F, Schonholzer C: Citrate anticoagulation in continuous venovenous hemodiafiltration: a metabolic challenge. Intensive Care Med 2002, 28: 1419-1425.

90. Dorval M, Madore F, Courteau S, Leblanc M: A novel citrate anticoagulation regimen for continuous venovenous hemodiafiltration. Intensive Care Med 2003, 29:1186-1189.

91. Cointault O, Kamar N, Bories P, Lavayssiere L, Angles O, Rostaing L, Genestal M, Durand D: Regional citrate anticoagulation in continuous venovenous haemodiafiltration using commercial solutions. Nephrol Dial Transplant 2004, 19:171-178.

92. Gupta M, Wadhwa NK, Bukovsky R: Regional citrate anticoagulation for continuous venovenous hemodiafiltration using calcium-containing dialysate. Am J Kidney Dis 2004, 43:67-73.

93. Bagshaw SM, Laupland KB, Boiteau PJ, Godinez-Luna T: Is regional citrate superior to systemic heparin anticoagulation for continuous renal replacement therapy? A prospective observational study in an adult regional critical care system. $J$ Crit Care 2005, 20:155-161.

94. Van der Voort PH, Postma SR, Kingma WP, Boerma EC, Van Roon EN: Safety of citrate based hemofiltration in critically ill patients at high risk for bleeding: a comparison with nadroparin. Int J Artif Organs 2006, 29:559-563.

95. Spronk PE, Steenbergen $\mathrm{H}$, ten Kleij M, Rommes JH: Re: Regional citrate anticoagulation does not prolong filter survival during CVVH. J Crit Care 2006, 21:291-292.

96. Gabutti L, Ferrari N, Mombelli G, Keller F, Marone C: The favorable effect of regional citrate anticoagulation on interleukin1 beta release is dissociated from both coagulation and complement activation. J Nephro/ 2004, 17:819-825.

97. Bos JC, Grooteman MP, van Houte AJ, Schoorl M, van Limbeek J, Nubé MJ: Low polymorphonuclear cell degranulation during citrate anticoagulation: a comparison between citrate and heparin dialysis. Nephrol Dial Transplant 1997, 12:1387-1393.

98. Gritters M, Grooteman MP, Schoorl M, Schoorl M, Bartels PC Scheffer PG, Teerlink T, Schalkwijk CG, Spreeuwenberg M, Nubé $\mathrm{MJ}$ : Citrate anticoagulation abolishes degranulation of polymorphonuclear cells and platelets and reduces oxidative stress during haemodialysis. Nephrol Dial Transplant 2006, 21: 153-159.

99. Wang PL, Meyer MM, Orloff SL, Anderson S: Bone resorption and "relative" immobilization hypercalcemia with prolonged continuous renal replacement therapy and citrate anticoagulation. Am J Kidney Dis 2004, 44:1110-1114. 